\title{
Saberes docentes na educação de jovens e adultos em Florianópolis (SC)
}

\author{
Cláudio Roberto Antunes Scherer Júnior* \\ Claricia Otto**
}

\begin{abstract}
Resumo
A Educação de Jovens e Adultos (EJA) em Florianópolis é colocada em ação pela via da Pesquisa como Princípio Educativo (PPE). Essa estratégia implica uma série de especificidades nos modos de materializar os processos de ensino e aprendizagem, bem como nas maneiras de se conceber a ação docente. Utilizando uma metodologia de tipo etnográfica e por meio de observações de campo e entrevistas, este artigo busca compreender algumas nuances sobre os saberes docentes dos professores dessa modalidade peculiar de ensino. A categoria, saberes docentes, é compreendida por meio de Tardif (2000; 2010; 2013). Nessa direção, algumas formas de se materializar a ação docente, em contexto de sala de aula, propiciaram a identificação e análise de saberes docentes intimamente ligados ao trabalho coletivo, à proximidade e à humanização.
\end{abstract}

Palavras-chave: saberes docentes, educação de jovens e adultos, pesquisa como princípio educativo.

Teachers' knowledge in youth and adult education in Florianópolis (Santa Catarina)

\begin{abstract}
Youth and Adult Education (Educação de Jovens e Adultos - EJA) in Florianópolis - Santa Catarinais implemented through Research as an Educational Principle (Pesquisa como um Princípio Educativo $P P E$ ).This strategy implies some specificities in ways of materializingthe teaching and learning processes, also conceiving the teaching action.Using an ethnographic methodology through field observations and interviews, this article aims to understand some nuances about the teachers' knowledge of this peculiar teaching modality.The category, teachers' knowledge, is approached through Tardif(2000; 2010; 2013). Thus, some forms of materializing the teaching action into the classroom context allowed the identification and analysis of teacher knowledge, closely linked to collective work, proximity and humanization.
\end{abstract}

Keywords: teachers' knowledge, youth and adult education, research as an educational principle.

\section{Introdução}

A Educação de Jovens e Adultos (EJA), em Florianópolis (SC), é colocada em ação por meio de um procedimento didático pedagógico denominado de Pesquisa como Princípio Educativo (PPE). Nessa modalidade, os estudantes são estimulados a desenvolverem pesquisas de seu interesse e essas são a parte central das atividades e, portanto, não existe delimitação de tempo e espaço entre as diferentes disciplinas, ou

\footnotetext{
* $\quad$ Mestre em Educação pela Universidade Federal de Santa Catarina (UFSC), membro do Grupo de pesquisa Patrimônio, Memória e Educação (PAMEDUC). E-mail: claudioschererjr@ yahoo.com.br.

** Doutora em História, professora do Departamento de Metodologia de Ensino e do Programa de Pós-Graduação em Educação da Universidade Federal de Santa Catarina. E-mail: clariciaotto@gmail.com.
} 
seja, os estudantes não têm aulas de História, Matemática, Português, entre outras. As diferentes áreas de conhecimento são contempladas via desenvolvimento das pesquisas. Os professores das diferentes áreas de conhecimento são os orientadores que auxiliam os grupos de pesquisa. Está organizada em Núcleos, sediados, a maioria deles, em escolas básicas municipais. Cada núcleo é nomeado conforme a região da cidade mais um número romano. Nesta pesquisa foram investigados os núcleos EJA Norte I e EJA Norte II, ambos localizados na região norte da Ilha de Santa Catarina. Cada núcleo é dividido internamente entre primeiro segmento (anos iniciais do ensino fundamental) e segundo segmento (anos finais do ensino fundamental). Os estudantes do primeiro segmento contam com uma professora pedagoga, responsável, principalmente, pelo letramento e alfabetização. Os do segundo segmento são os que trabalham diretamente com pesquisas e contam com professores de Artes (Cênicas ou Plásticas), Ciências (Biologia), Educação Física, Espanhol, Geografia, História, Matemática e Português.

Os professores necessitam acionar e/ou desenvolver conhecimentos inerentes à prática docente nesse contexto, ou seja, construir caminhos, sendo muitos deles desconhecidos em práticas docentes anteriores. Nessa direção, este artigo tem seu foco justamente nessas características específicas da ação dos professores, que é compreendida por intermédio da categoria saberes docentes segundo cunhado por Tardif (2000; 2010; 2013). Para Tardif (2010, p. 36), "pode-se definir o saber docente como um saber plural, formado pelo amálgama, mais ou menos coerente, de saberes disciplinares, curriculares e experienciais." O saber docente não provém de uma única fonte, ele é uma mistura, um "amálgama" provindo de diversos lugares e momentos da vida dos professores, isso quer dizer, não apenas de sua formação acadêmica, mas também de uma série de experiências vividas.

Tardif (2010, p. 255, grifo do autor), propõe pensar os saberes docentes pelo viés de uma epistemologia da prática profissional, que seria "o estudo do conjunto dos saberes utilizados realmente pelos profissionais em seu espaço de trabalho cotidiano para desempenhar todas as suas tarefas". Assim como Tardif (2000, p. 10-11), “damos aqui à noção de 'saber' um sentido amplo, que engloba os conhecimentos, as competências, as habilidades (ou aptidões) e as atitudes, isto é, aquilo que muitas vezes 
foi chamado de saber, saber-fazer e saber-ser." Os professores da EJA no desenvolvimento das atividades desenvolvem conhecimentos, habilidades e saberes:

\begin{abstract}
O saber dos professores deve ser compreendido em íntima relação com o trabalho deles na escola e na sala de aula. Noutras palavras, embora os professores utilizem diferentes saberes, essa utilização se dá em função do seu trabalho e das situações, condicionamentos e recursos ligados a esse trabalho. Em suma, o saber está a serviço do trabalho. Isso significa que a relação dos professores com os saberes nunca são relações estritamente cognitivas: são relações mediadas pelo trabalho que lhes fornece princípios para enfrentar e solucionar situações cotidianas (Tardif, 2010, p.16-17).
\end{abstract}

É no ambiente de ensino, no chão da sala de aula, que os saberes docentes dos professores da EJA podem ser identificados. Por isso, este trabalho tem a característica de ser um estudo de tipo etnográfico, que segundo Willis e Trondman (2008, p. 211) são um conjunto

\footnotetext{
de métodos que envolvem um contato social direto e sustentado com agentes, escrevendo ricamente o encontro, respeitando, registrando, representando, pelo menos em parte, a irredutibilidade da experiência humana, nos seus próprios termos. A etnografia é o registro-testemunhal disciplinado e deliberado de acontecimentos humanos.
}

Willis e Trondman (2008) deixam clara a irredutibilidade da experiência humana, ou seja, muito embora todos os esforços empreendidos, jamais é possível uma total compreensão do objeto proposto, antes sim, via esse contato direto, é possível criar um registro disciplinado dessa realidade, ter uma percepção cotidiana do trabalho dos professores da EJA de Florianópolis.

A etnografia na sala de aula, de acordo com Lima (2011, p. 81), baseada em Rockwell (2011), "é descrita como um enfoque ou uma perspectiva investigativa na qual se descrevem ambientes e se narram processos que não estão explicitados em nenhum discurso oficial, mas que dizem muito sobre o que está em jogo na educação". A intenção foi perceber indícios e sinais, possíveis apenas por meio do contato direto com o objeto investigado. Nas observações também produzimos um Diário de Campo (2016).

A produção de fontes orais foi extremamente importante para alcançar os objetivos desta pesquisa, para isso foram realizadas entrevistas com os professores dos respectivos núcleos. Pelas observações e entrevistas, ambas realizadas no ambiente de 
ensino, ou seja, onde a ação profissional dos professores se materializa, que se buscou identificar e compreender os saberes docentes na EJA na direção apontada por Tardif (2013, p. 568, grifo nosso):

Os conhecimentos dos professores não são a soma de 'saberes' ou de 'competências' que poderiam ser descritos e encerrados num livro ou num catálogo de competências. São saberes integrados às práticas diárias de ensino que são, em grande parte, sobredeterminados por questões normativas ou até mesmo éticas e políticas.

Nessa direção, características específicas das práticas de ensino dos professores na EJA de Florianópolis se destacaram durante o processo investigativo. Todavia, antes de adentrar nessas práticas, considerações a respeito dos saberes experienciais parecem pertinentes e ajudam a compreender o que propomos aqui. Segundo Tardif (2010, p. 38 e 39), “os próprios professores, no exercício de suas funções e na prática de sua profissão, desenvolvem saberes específicos, baseados em seu trabalho cotidiano e no conhecimento de seu meio. Esses saberes brotam da experiência e são por ela validados." Esses saberes estão intimamente ligados à realidade de trabalho e ao convívio com colegas mais experientes.

Pode-se chamar de saberes experienciais o conjunto de saberes atualizados, adquiridos e necessários no âmbito da prática da profissão docente e que não provêm das instituições de formação nem dos currículos. Estes saberes não se encontram sistematizados em doutrinas ou teorias. São saberes práticos (e não da prática: eles não se superpõem à prática para melhor conhecê-la, mas se integram a ela e dela são partes constituintes enquanto prática docente) e formam um conjunto de representações a partir das quais os professores interpretam, compreendem e orientam sua profissão e sua prática cotidiana em todas as suas dimensões. Eles constituem, por assim dizer, a cultura docente em ação (Tardif, 2010, p. 48-49).

Essa "cultura docente em ação" faz ser possível pensar nas diversas situações constituintes de saberes, envoltas nas possíveis atividades e tarefas inerentes ao trabalho dos professores, principalmente, nos docentes da EJA. Tardif (2010, p. 49, grifo do autor) afirma que,

[...] no exercício cotidiano de sua função, os condicionantes aparecem relacionados a situações concretas que não são passíveis de definições acabadas e que exigem improvisação e habilidade pessoal, bem como a capacidade de enfrentar situações mais ou menos transitórias e variáveis. Ora, lidar com condicionantes e situações é formador: somente isso permite 
ao docente desenvolver os habitus (isto é, certas disposições adquiridas na e pela prática real), que lhe permitirão justamente enfrentar os condicionantes e imponderáveis da profissão.

Lidar com essas condicionantes e situações inerentes ao desenvolvimento das ações dos professores faz parte dos momentos de formação. Uma formação mediada pelo enfrentamento de momentos inesperados, transitórios e variáveis comuns em ambientes de ensino. Portanto, ao considerar a ação docente, mediante os momentos de formação ligados a situações não previsíveis de sala de aula, somado ao conceito de saberes experienciais, ou seja, conhecimentos docentes acionados e adquiridos nas interações ligadas às práticas reais de ensino, é que torna possível pensar os saberes docentes na EJA de Florianópolis com a especificidade da PPE.

Com a ideia de saberes docentes formados por um amálgama de saberes, dentre eles os saberes experienciais; e de que o trabalho docente em situações reais de ensino proporciona ao professor o desenvolvimento de conhecimentos, possíveis apenas por meio da prática, é possível adentrar nas especificidades dos saberes docentes identificados nos Núcleos da EJA já referidos. Nas seções que seguem, apresentamos três concepções de saberes inerentes a esse contexto, envoltos da peculiaridade da PPE, ou seja, dos modos de trabalho advindos dessa perspectiva educacional específica.

"Não é só você ensinando, é todo mundo junto em um grupo"1: trabalho coletivo na ação docente

Dentre as especificidades do trabalho docente na EJA de Florianópolis, a principal característica é o trabalho coletivo. Tal especificidade aparece a todo instante nas práticas educativas da EJA: na reunião de planejamento ${ }^{2}$, nas atividades com os estudantes, nas pesquisas e nas saídas pedagógicas. Por isso, saber trabalhar coletivamente é essencial para um professor na EJA.

A nossa prática aqui (na EJA), acho que abre as possibilidades para você ver o que pode fazer que torna, não só a tua aula, mas o conhecimento mais

Professora Minerva, entrevista, 2016, p. 5.

Em 2016, os professores e o coordenador do Núcleo se reuniam em formações descentralizadas, chamadas de reuniões de planejamento, todas as segundas e quartas-feiras à tarde. Nessas reuniões são debatidas as ocorrências no Núcleo: problemas de disciplina, dificuldades nas pesquisas, etc.; e são feitos planejamentos: encaminhamentos para as pesquisas em andamento, atividades artísticas, passeios pedagógicos, entre outros. 
interessante, te abre possibilidades para você pesquisar. A questão da docência da EJA é você compartilhar. Eu me sinto muito feliz, muito, muito mesmo! Porque quando você entra em uma sala de aula, no Ensino Fundamental e no Ensino Médio, você ali é o responsável, você precisa dar conta, é você e você. Enquanto que na EJA é o grupo, não é você. Se algo der certo é fruto do grupo, e se algo der errado também é fruto do grupo. Essa docência compartilhada é muito boa, para mim é muito prazerosa. E, como a gente troca conhecimento, a gente aprende com o outro colega (Prof ${ }^{a}$. Pro, entrevista, 2016, p. 3).

Saber trabalhar em grupo é o que a professora Pro $^{3}$ chama de docência compartilhada, é parte intrínseca da ação docente na EJA. Isso significa um compartilhamento dos sentimentos que as práticas docentes podem trazer, ou seja, a satisfação da conclusão de uma atividade considerada bem sucedida e as agruras de outra que acabou não dando certo e, por consequência, esses sentimentos, ao serem absorvidos de forma conjunta, causam menos impacto nos professores. Quando um professor propõe uma atividade na reunião de planejamento e, após discussão, é aceita, todo o grupo passa a ter a responsabilidade para com a execução dessa ação pedagógica, todos têm a meta de obter o melhor resultado possível, pois o grupo passa a ser o responsável. Logicamente, o professor promotor da ideia pode ser um tipo de guia principal da atividade. O trabalho coletivo da EJA exige dos professores um saber ouvir o outro e buscar compreender suas ideias. As reuniões de planejamento, fundamentais para a existência da EJA via PPE, também são importantes para o estabelecimento de laços de solidariedade e amizade profissional, essenciais para desenvolver um sentimento de grupo.

Segundo Tardif (2010, p. 101), “o professor tende, com frequência, a aderir aos valores do grupo; ele partilha com outros membros sua vivência profissional e troca com eles conhecimentos sobre diversos assuntos. Em suma, torna-se um membro familiarizado com a cultura de sua profissão". A experiência docente da EJA maximiza essa constatação apontada pelo autor. Mais do que "aderir aos valores do grupo", o professor deve aderir ao grupo em si, pois, em diversos momentos, um vai precisar do outro, seja para conter situações de desordem, seja para auxiliar em determinada atividade, seja para compartilhar conhecimentos específicos:

A questão da aula, para mim, como é que foi encarar isso? Em primeiro lugar, bem desafiante, porque eu sabia que teriam coisas lá que não são da minha área, embora eu não acredite muito nessa coisa de você ter de saber muita coisa sobre uma coisa só, você tem de saber poucas coisas sobre

3 Os próprios docentes entrevistados definiram cada um dos pseudônimos aqui utilizados. 
muitas coisas, especialmente hoje em dia, mas, eu sabia que teriam coisas que eu não saberia direito e tudo mais, mas, ao mesmo tempo todos os professores sempre foram bem legais, bem convidativos: 'Relaxa! Se você não souber alguma coisa a gente vai estar lá para te ajudar também!' Mas você acaba pegando, tudo vai seguindo certa metodologia, então você acaba sentindo como funciona aquilo lá e você vê que de início o conhecimento que eu tenho dá para ajudar $95 \%$ das pesquisas, de repente $90 \%$, os $10 \%$ são coisas bem específicas. Tem uma lá, que o cara está falando sobre a história do Fusca, então, ontem eu falei: Oh, tu vais ter de falar com o (professor), ele é mecânico e vai saber mais sobre isso aí. Eles vão, falam e voltam, mas na grande maioria das pesquisas, grande parte delas, você acaba adquirindo conhecimento e fala: Oh, segue por esse caminho, segue por ali (Prof. Virgulino, entrevista, 2016, p. 2 e 3, grifo nosso).

Essas situações narradas pelo professor Virgulino são comuns na EJA. Os professores, na primeira experiência, sempre têm receio de trabalhar a PPE, sentem insegurança. Mas, pelo relato do professor Virgulino, podemos citar pelo menos dois motivos que ressaltam a importância de se trabalhar em grupo no desenvolvimento do PPE: 1) ter sempre alguém próximo para auxiliar em momentos de incertezas e dúvidas, principalmente nos primeiros dias de trabalho nos Núcleos, e; 2) poder contar com os conhecimentos mais específicos dos colegas professores diante de situações que, sabidamente, outro professor proporcionará mais auxílio, seja porque diz respeito mais a sua área de formação, seja porque o professor possui mais interesse sobre determinando assunto.

Para saber trabalhar coletivamente é necessário abrir mão de algumas concepções rígidas, uma delas é de que o professor atuaria somente em questões e pesquisas que estivessem relacionadas mais diretamente com sua área de formação. Isso apareceu na fala do professor Virgulino e também na da professora Minerva:

\footnotetext{
Desapegar daquilo de dizer que 'eu sou da área de...' E, de repente, você se vê dando aula de matemática, de português, de geografia, e os alunos perguntam: 'Não, mas você não é professora de Artes?' (risos) Você está fazendo a mediação ali. E você acaba aprendendo com as outras pessoas, tanto com os professores, quanto com os alunos, não é só você ensinando, é todo mundo junto em um grupo (Prof ${ }^{a}$. Minerva, entrevista, 2016, p. 5).
}

As áreas de conhecimento existem e são fundamentais no desenvolvimento das pesquisas, mas não significa uma barreira na atuação dos professores da EJA. Elas são balizas em que o objetivo é trabalhar com as interligações e diálogos possíveis de serem construídos e cuja tarefa depende do trabalho dos docentes, que são os 
responsáveis por essas interligações entre áreas. Para Minerva, não é apenas um professor que ensina, mas sim, "todo o grupo junto", isso é um dos principais elementos constituidores dos saberes docentes no que diz respeito ao saber trabalhar coletivamente. Sem essa concepção, as práticas educativas podem ser obstaculizadas, o que dificultaria os processos da PPE. A professora Andrômeda relatou uma situação que exemplifica alguns problemas no saber trabalhar em grupo:

Então, sabes que no primeiro ano aqui eu fiquei traumatizada por isso, porque, era um bom grupo de professores, mas tinha um ou dois que eram meio problemáticos, não porque não entendiam a proposta, mas porque era difícil dialogar com eles. Eu não lembro muito bem os motivos, mas em vários momentos havia conflitos na reunião, havia discórdia. Em vários momentos eu saía da reunião para tomar uma água porque não estava aguentando aquele clima! (Prof ${ }^{\mathrm{a}}$. Andrômeda, entrevista, 2016, p. 4).

Momentos de conflitos não foram presenciados nas observações em campo, ao contrário, mesmo em situações discordantes, em que um professor era contrário à ideia de outro, o diálogo tomou o rumo de uma discussão construtiva, em que o objetivo do grupo era encontrar a melhor maneira de compreender determinada situação. Os coordenadores parecem exercer uma função importante no controle do fluxo das conversas, no sentido de evitar divagações e buscar uma solução. Era habitual, após expostas algumas opiniões, o coordenador fechar perguntando: "E aí? Qual a solução disso? O que podemos fazer?" E chagava-se a uma decisão, nem sempre unânime, mas aceita pelo grupo (DIÁRIO, 2016). Todavia, Pro também relatou situações conflitantes.

É um prazer muito grande! Não venho para a EJA: Ah! Meu Deus, que saco, mais um dia! Tem coisas boas e tem muito problema no meio também, que dá um baque, que faz a gente pensar. Eu acho que o coletivo ajuda muito nesses caminhos, fortalece bastante. Eu já estive em um ano que o nosso coletivo não foi tão entrosado, foi mais entroncado o negócio, mas também faz parte, é aprendizagem. Mas é bastante prazeroso também (Prof ${ }^{a}$. Pro, entrevista, 2016, p. 7).

Mesmo relatando o prazer de trabalhar na EJA de Florianópolis, essa professora também pensa em momentos de "baque", em situações difíceis. Nesses momentos, em sua opinião, "o coletivo ajuda muito, [...] fortalece bastante". Parece que ao rememorar essas situações, uma sequência lógica de ponto e contraponto dessas situações vai surgindo em sua mente. Quando pensa na satisfação de trabalhar na EJA, lembra que existem problemas. Quando pensa no coletivo como auxiliador desses momentos de 
problemas, rememora que nem sempre o coletivo é "entrosado". Na opinião de outra entrevistada, o relacionamento interpessoal no ambiente de trabalho na EJA é fundamental.

\begin{abstract}
A relação é outra. E, às vezes, na relação entre professores a gente tem de ter mais sensibilidade do que com o próprio aluno, na verdade com os dois, mas a convivência com o colega é maior do que com a minha própria família, eu convivo muito mais com os meus colegas do que com o meu marido, por exemplo. Então, a gente tem que ter uma boa convivência, no momento que a gente não consegue dialogar e ouvir o colega é muito difícil conviver e trabalhar junto, mas no momento que tu consegues lidar com esses conflitos e ter um bom trabalho, consegues desenvolver legal. Eu acho que vai um pouquinho da pessoa também, porque tem pessoas que pelo mínimo já criam conflitos (Profa. Andrômeda, entrevista, 2016, p. 4).
\end{abstract}

O universo de trabalho em um Núcleo de EJA em Florianópolis envolve pelo menos oito professores, mais um coordenador, uma auxiliar de ensino, uma pedagoga ( $1^{\circ}$ segmento); além disso, uma cozinheira, uma auxiliar de serviços gerais e um vigia. Todos, de formas diferentes, estão envolvidos nos processos educativos desenvolvidos na escola. Alguns, logicamente, de modo direto, outros, indiretamente. São várias personalidades diferentes, envolvidas num processo de ensino que necessita de uma interação e diálogo, por isso, conflitos e desavenças são vistas como normais. Andrômeda parece ter clareza quanto a isso, principalmente sobre a importância de dialogar e de ouvir, para "lidar com esses conflitos e ter um bom trabalho".

Zeichner (1997c, p. 1), conforme citado por Laffin (2013, p. 47), enfatiza a importância de o professor saber trabalhar em grupo: "é no grupo e através dele que os professores podem apoiar e sustentar o crescimento uns dos outros. Quando os professores trabalham sozinhos são fracos, quando eles trabalham em grupos se tornam mais fortes dentro da instituição”. Nessa mesma direção, Laffin $(2013$, p. 48) cita as indicações de Geraldi, Florentin e Pereira (1998, p. 259): “O grupo oferece a vantagem de os professores poderem apoiar-se e contribuir para o conhecimento uns dos outros. Além disso, os professores veem que os seus problemas não são só seus e têm relação com o dos outros professores ou com a estrutura das escolas e os sistemas educacionais". A fala da professora Tina corrobora essas indicações:

Eu, gosto, gosto bastante, principalmente da parte da docência compartilhada. Acho muito importante porque, muitos professores têm dificuldade em lidar com a docência compartilhada, e eu, gosto muito! 
Porque, às vezes, em momentos difíceis você tem com quem contar, situações de conflito em sala, alguma coisa assim, às vezes, você não sabe muito bem como vai resolver, e, o outro professor está de fora e está mais tranquilo, então eu acho importante essa parte, ou até, às vezes, você vê que o outro professor está meio perdido e não sabe muito bem lidar com a situação e você pode ajudá-lo, isso é muito importante, ter essa docência compartilhada. Acho legal ter dois professores por sala (Prof ${ }^{a}$. Tina, entrevista, 2016, p. 6).

O apoio mútuo, o companheirismo, a ajuda nas atividades pedagógicas e os diálogos são parte integrante do ser professor na EJA de Florianópolis. Nesse sentido, o saber docente atrelado a esse contexto é o de saber trabalhar coletivamente, saber trabalhar em grupo, saber compartilhar a docência.

Na seção a seguir abordamos questões ligadas às relações de proximidade desenvolvidas no contexto da EJA que são possibilitadas pela PPE e facilitadas pelo saber trabalhar coletivamente.

\title{
"A gente senta junto, eu sento, não explico" ${ }^{4}$ : proximidade na ação docente
}

O trabalho dos professores na EJA está envolto em um constante diálogo entre eles próprios e os estudantes. Essa situação constitui um ambiente de trabalho propício para a construção e manutenção de situações de proximidade interacionais. É mais uma concepção de trabalho do professor, de modo geral, fortemente ligada às interações humanas, conforme elucidado por Tardif (2010, p. 118):

\begin{abstract}
Ao entrar em sala de aula, o professor penetra em um ambiente de trabalho constituído de interações humanas. As interações com os alunos não representam, portanto, um aspecto secundário ou periférico do trabalho dos professores: elas constituem o núcleo e, por essa razão, determinam, a nosso ver, a própria natureza dos procedimentos e, portanto, da pedagogia.
\end{abstract}

Na EJA de Florianópolis, devido aos modos de trabalho da PPE, essas interações são ampliadas e maximizadas. Ao analisar a prática docente dos professores partícipes desta pesquisa, ao visualizar a maneira como as atividades nos Núcleos aconteciam, o modo como cada professor se portava, a forma como cada um materializava suas concepções do que é ser professor na EJA; tudo isso evidenciou que as interações humanas nesse ambiente de ensino têm a proximidade como uma das 
principais características. A ação pedagógica na EJA possibilita o que foi observado nos Núcleos e denominado pelos envolvidos no processo educativo de "sentar junto" ou "sentar lado a lado". Andrômeda menciona essa característica:

Total, com os alunos permanentes, a gente senta junto, eu sento. Dificilmente eu vou para o quadro explicar alguma coisa, só quando é algo de interesse de todos, mas a conversa é lado a lado, a gente senta junto, conversa junto, lê junto, vamos tentar fazer um resumo juntos: 'o que tu entendestes?' A conversa é muito íntima, a aproximação é total e não só com os alunos, mas com alguns colegas de trabalho, no sentido de como a gente tem a regência compartilhada, então tem de ter certa proximidade para ter essa sensibilidade de conversar, de ver até que ponto eu posso, porque, em vários momentos, e isso é uma aprendizagem também, eu tive atitudes, na minha espontaneidade de definir coisas sem consultar o colega, e, o colega não gostou, veio e disse: 'olha, eu não gostei do que tu fizestes, e eu disse: 'me desculpa eu nem prestei atenção'. Eu chamei a turma para outra sala, e ela: 'mas como tu não passou por mim?!' Ter esse diálogo, ter essa comunicação é muito importante, definir as coisas juntos, não definir sozinho, a gente está numa equipe, então, tem de ter essa proximidade, e com os alunos o tempo todo também, até porque para tu criar vínculos, e isso até com os meus alunos do 'regular', eu tento ter uma proximidade, pergunto da família, o que gosta de fazer, o que quer ser quando crescer, para os pequenos, mas para os adultos também, eu tento conversar fora da sala de aula, no intervalo. Muitos são meus vizinhos, então tem uma proximidade, nesse sentido, eu vou e volto de bicicleta, muitos também, e a gente vem e volta juntos. Então, essa troca fora de sala de aula é super importante, eles criam certa relação contigo que favorece também no pedagógico, então, penso que é importante ter essa aproximação, não só como docente, mas como um amigo, uma pessoa que tu podes ter contato (Prof ${ }^{\mathrm{a}}$. Andrômeda, entrevista, 2016, p. 4 e 5).

Essa fala da professora Andrômeda contém muitas informações. Evidencia as práticas de ensino com os alunos numa relação mais próxima, uma maneira de colaborar com cada estudante de modo individualizado. A possibilidade de sentar junto com o estudante, ler junto, trabalhar em conjunto com o discente, lado a lado, conforme também observado na pesquisa de campo, é uma das principais características da ação docente da EJA de Florianópolis.

A docência compartilhada surge no discurso da professora Andrômeda evidenciando que saber relacionar-se compartilhando situações da vida e do trabalho com os colegas professores, também auxilia na prática docente em sala de aula. Isso facilita e propicia a percepção de que o professor na EJA se torna "uma pessoa que tu podes ter contato.” Essas questões vão na direção apontada por Santos (2011, p. 153): 
As relações socioafetivas, do nosso ponto de vista, estabelecem, criam e ampliam os vínculos entre sujeitos, bem como possibilitam diálogos horizontais e desenvolvem um respeito mútuo na interação cotidiana, fazendo parte, desse modo, de um viver a profissão docente. Ressaltamos, ainda, que as relações socioafetivas não se confundem com uma perspectiva assistemática, espontaneísta de desenvolvimento da prática.

Santos (2011, p. 153), com base em Freire (1987, p. 79), ainda enfatiza que essas relações "dizem respeito, especificamente, a uma prática orientada pelo princípio do diálogo entendido como 'uma exigência existencial', vivenciando uma docência afetivamente implicada". Essa docência afetivamente implicada diz respeito a uma concepção de professor que parece estabelecer como principal característica um saber docente associado ao saber estar próximo, seja dos alunos, seja dos outros docentes. Na EJA em Florianópolis, isso se refere aos professores inseridos em um amplo horizonte de situações interacionais dialógicas próximas, que são percebidas não apenas entre alunos e professores, mas também entre os docentes. O professor Virgulino apresenta essa ideia, na satisfação em falar sobre seus colegas: "O time daqui é excelente! A equipe daqui é excelente! Eles são muito legais, eles estão sempre lá te ajudando, é uma proximidade e uma parceria muito boa" (Prof. Virgulino, entrevista, 2016, p. 6).

Esse "saber estar próximo" que o professor desenvolve ao trabalhar na EJA colabora para a atuação docente nesse ambiente específico de ensino, muito embora também seja uma característica ideal das interações pedagógicas em geral, como pontuado por Tardif (2010, p. 167):

\footnotetext{
Ensinar é entrar numa sala de aula e colocar-se diante de um grupo de alunos, esforçando-se para estabelecer relações e desencadear com eles um processo de formação mediado por uma grande variedade de interações. A dimensão interativa dessa situação reside, entre outras coisas, no fato de que embora possamos manter os alunos fisicamente numa sala de aula, não podemos obrigá-los a participar de um programa de ação comum orientado por finalidades de aprendizagem: é preciso que os alunos se associem, de uma maneira ou de outra, ao processo pedagógico em curso para que ele tenha alguma possibilidade de sucesso.
}

Essa dimensão interativa do ato de ensinar é influenciada diretamente por essa variável que o autor denomina de "associação dos alunos ao processo pedagógico". A proximidade, desenvolvida e estimulada pelas práticas docentes inerentes aos trabalhos na EJA, por meio da PPE, proporciona uma relação de conhecimento mútuo, ou seja, 
uma relação mais próxima entre docentes e estudantes, em que ambos se conhecem com vistas ao desenvolvimento de momentos de aprendizagem.

Um fato comum nos dois Núcleos auxilia na compreensão de um momento que, mesmo sendo algo corriqueiro, pode simbolizar a possibilidade de interação, e que na EJA é uma situação diária, se refere ao momento da janta. Os núcleos de EJA de Florianópolis contam com cozinheiras responsáveis por fazer a janta, todas as noites, de segunda à sexta-feira. A maioria dos professores janta com os estudantes, comendo as mesmas comidas, sentando lado a lado nas mesmas mesas, compartilhando os mesmos utensílios e, logicamente, conversando sobre os mais diversos assuntos. Esses momentos de diálogo coadunam com a ideia de interação na relação com os estudantes.

Compartilhar o alimento funciona como um momento dialógico intenso, de trocas de informações entre os sujeitos que transpassa a relação hierárquica conhecimento/professor/aluno, pois, no momento da janta, professor e aluno estão sentados juntos, lado a lado, compartilhando interesses e opiniões. Nem todos os professores participam desse momento; alguns ficam mais isolados, ficam na Sala da EJA, ou ficam por perto conversando com outros estudantes que não jantam (DIÁRIO, 2016). Não existe uma obrigatoriedade de permanecer com os estudantes nos intervalos, mas aqueles que optam por jantar e compartilhar desse momento contribuem para a construção de maior interação.

Muitas vezes, durante esses momentos de diálogo, várias informações eram obtidas sobre os estudantes. Essas informações são compartilhadas nas reuniões de planejamento com vistas a melhorar a aprendizagem de determinados alunos.

A gente descobre que tem um monte (de estudantes) por aí que se forma sem saber nada, e a gente descobre que ele não sabe nada. Quando a gente descobre que ele não sabe nada, nós vamos lá e ajudamos. Descobrimos que um monte que ficou (na EJA), sabe muita coisa e foi menosprezado. A gente descobre tudo. Cada um tem o seu tempo, mas tem aqueles que não conseguem mesmo, e a gente descobre, é legal isso, pois, com esse tipo de filtro que a gente faz, não é filtro, com esse acompanhamento que a gente faz, não tem como não ver que ele não sabe escrever, que não sabe ler, a gente descobre. No fundamental 'normal' não tem como descobrir. (Por que tu achas que vocês descobrem isso?) Porque a gente senta do lado dele. 'Cara, vamos fazer um negócio assim'. Daí ele não consegue formar uma frase, formar nada. Aí você descobre que ele não consegue. Vai, numa boa e pergunta: 'Vamos escrever tal coisa? Fazer não sei o quê?'Aí, você descobre se ele é copista, se ele não sabe ler; você sozinha com ele. Você 
sente que não está indo, você vai lá e vê o porquê (Prof ${ }^{a}$. MacGyver, entrevista, 2016, p. 5 e 6 , grifo nosso).

O ato de "sentar junto" de "sentar lado a lado" com os estudantes na EJA é algo recorrente nos núcleos e as falas dos professores entrevistados vão nessa direção. Saber ser/estar próximo se configura num conhecimento valioso nas interações pedagógicas na EJA. Um professor com um perfil retraído, com uma personalidade mais tímida, tem mais dificuldades de acionar e desenvolver esse conhecimento; nesses momentos, o trabalho coletivo, a docência compartilhada é fundamental para superar essa barreira a respeito de interações. Santos (2011, p. 150) ratifica tais observações em pesquisa sobre os saberes necessários para a docência na EJA:

\footnotetext{
No âmbito do ensinar e do aprender, outro aspecto observado e vivido no cotidiano da sala de aula diz respeito às relações socioafetivas. A afetividade na interação educadores e educandos parece, em muitos momentos, inerente ao trabalho pedagógico nessa modalidade, extrapolando o próprio contexto da sala de aula e instituindo-se em ambientes como a casa, o ônibus, a rua, o bairro, entre outros.
}

É nessa direção que caminha a EJA de Florianópolis. As possibilidades proporcionadas pelo modo de trabalho, ou seja, por práticas e rituais pertinentes a uma formação pela prática profissional, intensifica as interações pedagógicas próximas inerentes a esse trabalho docente. Na próxima seção analisamos uma característica necessária para que essa proximidade exercida pelos docentes da EJA não seja apenas uma questão corporal, ou seja, um estar próximo num sentido apenas físico, pois, sem um olhar humanizado para os sujeitos, essa proximidade poderia não ter uma afetividade/efetividade pedagógica.

\section{"Humanização é isso!": humanização na ação docente}

O trabalho coletivo somado à proximidade das práticas pedagógicas observadas envolve o professor numa teia de relações entre sujeitos que possibilitam uma interação peculiar e possível em decorrência da PPE. Essa proximidade visualizada no cotidiano dos trabalhos na EJA necessita de uma percepção docente que deve estar 
atenta e sensível para o lado humano das interações, em que o aluno é visto como uma pessoa, além de ser um estudante.

Nesse sentido, o professor da EJA necessita ter um olhar humanizado, que leva em consideração o contexto do qual emerge o sujeito estudante. As minúcias reveladas nas interações que, sem humanização, não passam de informações, podem ser tratadas como um conhecimento fundamental para auxiliar os alunos nos mais diversos assuntos, não apenas em questões escolares. Ter um saber humanizado significa dizer que é necessário um olhar sensível, social e humano.

Eu acho que a coisa mais importante, que eu ressalto na EJA é a questão da humanidade e do acolhimento. Isso é o ponto mais positivo na EJA. Porque a gente trabalha com uma parte dos jovens e até adultos ou idosos, a parte mais excluída da sociedade, excluída da escola, excluída do mercado de trabalho. Então, para ser professor na EJA, você não tem que ter só a sua especialidade na sua licenciatura, na sua área, você tem que ser uma pessoa que gosta de ter esse trabalho um pouco voltado para essa parte social mesmo, você tem de gostar disso, porque você trabalha com isso e é um trabalho muito bonito que a gente faz aqui na EJA de Florianópolis. Eu sinto que a maioria do corpo docente e mesmo a direção, tem essa parte humana, uma parte de você estar despojado dos preconceitos e sempre disposto a acolher o aluno, a tentar ver o aluno num contexto social, num contexto amplo, não tentando enquadrar. Isso é a parte que eu mais admiro na EJA, essa parte, sempre gostei e talvez por isso que me identifiquei tanto com o trabalho (Prof ${ }^{a}$. Tina, entrevista, 2016, p. 4, grifo nosso).

Esse saber humanizante da ação docente, que é percebido na fala da professora Tina, corrobora a ideia de que o professor, em sala de aula, desenvolve interações com seus estudantes que tendem a transcender uma mera mediação de conhecimentos. A suposição de que o aluno é alguém além de tão somente um estudante, colabora para pensar nas variáveis que influenciam direta ou indiretamente nas atividades discentes nos núcleos da EJA. Sem esse olhar humanizado, ou seja, sem a sensibilidade no trato com os diversos problemas e angústias que assolam os sujeitos nos núcleos, parte significativa da aprendizagem por meio da PPE e suas diversas atividades educativas poderia não ter relevância efetiva no desenvolvimento dos estudantes, que por estarem na EJA, possuem de antemão alguns problemas em determinados aspectos ligados a sua escolarização anterior. Esse saber humanizado, saber ligado à sensibilidade do professor em sala de aula, mas também com os colegas de profissão, é possível porque parcela do trabalho docente é de cunho afetivo e emocional, baseia-se em afetos e emoções, na capacidade de sentir temores, alegrias e bloqueios afetivos, 
principalmente dos alunos (TARDIF, 2010). O professor Virgulino parece exemplificar essa percepção de emoções e temores:

\begin{abstract}
Num desses cursos de formação (centralizada), teve um senhor que dá aula lá no continente, e o cara falou que a gente está basicamente tratando de pessoas que foram rejeitadas pela escola e eles vem para cá. Então, eles já vêm com essa bagagem: 'de que isso nunca funcionou para mim, essa relação nunca deu certo para mim, para quê eu estou aqui?' Então, eu conhecendo esse cara (aluno) que me falou isso, eu sei, que se fosse assim não ia passar. Talvez agora passasse, com essas novas resoluções que você não vai ser reprovado, mas, ele não conseguiria fazer. Tem aquela centelha de esperança, de que: 'se eu copiar o que ele (professor) botar no quadro e só ler um pouquinho eu vou passar. É, eu consigo passar com aquela coisa: $2+2=4$ e se eu decorar isso eu passo'. Talvez não, porque eu conhecendo ele provavelmente não, inclusive um amigo dele naquela hora falou: 'Pow, tu é burro, como é que tu vai passar?' Eles mesmos sabem, mas eu acho que eles ainda querem essa coisa do tradicional, não é a maioria, mas todos foram rejeitados no ensino regular, eles não têm o fundamental completo, por isso eles estão aqui (Prof. Virgulino, entrevista, 2016, p. 3).
\end{abstract}

Portelli (1996, p. 5) diz que "os fatos importantes são os que se desenvolvem dentro da consciência”. Mesmo que Portelli não esteja tratando sobre a questão desse saber humanizado do professor da EJA, se aproxima de Virgulino que consegue apresentar as angústias e desafios que se impõem perante alguns dos alunos. Essa sensibilidade de compreensão para com os anseios dos discentes é importante, mas nem sempre presente; o olhar humanizado, ou seja, o olhar crítico-sensível é um aprendizado desenvolvido nas interações diárias na medida em que os professores vão observando as individualidades, conhecendo os alunos e adquirindo maior cuidado na relação com eles.

Essa relação e compreensão humanizadora de educação, de acordo com Santos (2011, p. 152), "possibilita trabalhar baseando-se na diversidade cultural dos sujeitos e, ao mesmo tempo, situar no centro da prática alfabetizadora o ser humano como sujeito pensante, estético, ético, político, cultural e, sobretudo, como sujeito de direitos".

Essa afirmação, ao que parece, se encaixa naquilo que é pretendido na EJA, a saber, que o sujeito estudante seja visto na sua individualidade e considerado como parte central dos trabalhos da PPE. Tal centralidade, ligada à proximidade na ação docente na EJA, possibilita a constatação e compreensão de algumas mazelas sociais e pessoais dos estudantes. O professor João, ao ser questionado sobre essa relação com os estudantes, relatou: 


\begin{abstract}
A gente até se preocupa com alguns casos, que sabemos ser uma situação de maior vulnerabilidade. Tiveram alguns casos esse ano, de querer ajudar o aluno, e acho que isso é em virtude da proximidade que a gente tem deles, essa questão da humanização, acho que tem todo o sentido (Prof. João, entrevista, 2016, p. 6).
\end{abstract}

Essa situação de querer ajudar estudantes, principalmente em circunstâncias de vulnerabilidade, pode ser vista por alguns como algo que está além das possibilidades do professor, em outras palavras, fora de sua esfera de atuação. Mas como pode ser visto pela fala da professora MacGyver, não seria essa a questão:

\footnotetext{
Você sabe os problemas, porque assim, eles (estudantes) acham que a gente pode ajudar nesse sentido também, aí tem essa troca. Falam que não pode ser assim, mas não sei, acho que tem de ser assim. Acham que não pode ser assistencialista, mas tem de ser assim, como não cuidar? Humanização é isso! Se um olhasse pelo outro, não estaria acontecendo o que está acontecendo. Bem assim, as pessoas não passariam fome...! (Prof ${ }^{a}$. MacGyver, entrevista, 2016, p. 9).
}

Parece não haver dúvidas quanto ao dever de tentar auxiliar os estudantes. Nesse excerto, é impossível saber quem, na opinião da professora MacGyver, acha que "não pode ser assistencialista". Certamente ela está se referindo a colegas, principalmente a colegas de profissão com uma visão menos aberta sobre a ação docente, talvez aquele tipo de professor que não se vê como educador, o que implicaria ter uma concepção mais ampliada de sua atuação, mas se vê apenas como um professor, responsável por conteúdos de sua área de conhecimento e tratados, apenas, em sala de aula.

Esse saber docente ligado à humanização do olhar do professor na relação com os estudantes é importante na prática profissional na EJA de Florianópolis, pois muitos dos educandos se encontram em situações de vulnerabilidade social e econômica.

\title{
Considerações finais
}

A EJA de Florianópolis possui uma série de especificidades nos modos de concepção dos processos educativos mediante a peculiaridade da PPE. Essa característica de ensino enseja o acionamento e/ou desenvolvimento de saberes docentes intrínsecos a esse contexto. As ideias e nuances apresentadas mostram algumas particularidades da EJA, promotoras de situações desafiadoras para os 
profissionais que ali atuam. Esses desafios, entendidos como situações e condicionantes da ação docente, são compreendidos como momentos proporcionadores de um tipo de formação, inseridos na dimensão da construção de saberes experienciais, como proposto por Tardif (2010).

Pela especificidade da PPE, os professores ampliam a concepção de sua atuação desenvolvendo alguns saberes que, nas observações e entrevistas, foram entendidos como formadores de um conjunto de conhecimentos intrínsecos aos trabalhos dos profissionais docentes. O trabalho coletivo foi entendido como o principal conhecimento necessário para os docentes, uma característica de ser um processo pedagógico feito em grupo, em que as reuniões de planejamento e as demais atividades com os estudantes são sempre mediadas pelo diálogo constante com outros colegas professores. Um ambiente que, com raras exceções, favorece interações dialógicas, o que gera vínculos e situações de comprometimento e auxílio entre os docentes.

A proximidade, entendida como um "saber estar próximo", não no sentido apenas físico, de sentar ao lado, junto, mas sim no sentido de conhecer mais intimamente os estudantes e, como foi constatado em algumas entrevistas, proximidade também com o colega professor, possibilita o desenvolvimento de uma relação entre docente/discente e docente/docente facilitadora dos processos educativos.

Um saber intimamente ligado com a proximidade inerente a esse contexto educativo é a humanização, um olhar humanizado para com os estudantes, o que significa ver o aluno inserido num contexto muito mais amplo, enxergá-lo como um sujeito, além de estudante. Esse saber humanizado está intimamente ligado à proximidade exercida nas atividades da EJA, pois as situações de proximidade sem esse olhar humanizado para esse sujeito estudante não seriam, a nosso ver, tão proveitosas em termos de aprendizagem. Esse olhar humanizado desenvolvido pelos docentes da EJA de Florianópolis percebe as diversas facetas do universo de vida dos estudantes, principalmente dos estudantes da EJA, sujeitos portadores de uma experiência de vida e de desafios ligados à (des)continuidade de sua escolarização.

A EJA, pelos saberes docentes aqui apresentados, pelo trabalho coletivo, pela proximidade e humanização, é por nós percebida como um contexto de ensino que 
insere os docentes em experiências geradoras de estranhamentos, essenciais para o crescimento pessoal e profissional dos docentes.

\section{Referências}

LAFFIN, Maria Hermínia Lage Fernandes. A constituição da docência entre professores de escolarização inicial de jovens e adultos. Ijuí: Unijuí, 2013.

LIMA, Laura Rodrigues de. "Uma das melhores coisas dentro dessa proposta é o espanhol": as jovens situações bilíngues encontrando maturidade na educação via pesquisa da EJA Florianópolis. 2011. Dissertação (Mestrado em Linguística). Universidade Federal de Santa Catarina. Florianópolis.

PORTELLI, Alessandro. A filosofia e os fatos: narração, interpretação e significados nas memórias e nas fontes orais. Tempo. Rio de Janeiro, v.1, n.2, 1996, p. 59-72.

SANTOS, José Jackson Reis dos. Saberes necessários para a docência na educação de jovens e adultos. 2011. Tese (Doutorado em Educação). Universidade Federal do Rio Grande do Norte. Natal.

SCHERER, Cláudio. Saberes docentes na Educação de Jovens e Adultos em Florianópolis (SC). 2017. Dissertação (Mestrado em Educação). Universidade Federal de Santa Catarina. Florianópolis.

TARDIF, Maurice. Saberes docentes e formação profissional. Petrópolis: Vozes, 2010.

Saberes profissionais dos professores e conhecimentos universitários: elementos para uma epistemologia da prática profissional dos professores e suas consequências em relação à formação para o magistério. Revista Brasileira de Educação, $\mathrm{n}^{\circ}$. 13, 2000. p. 5-24.

. A profissionalização do ensino passados trinta anos: dois passos para frente, três para trás. Educação \& Sociedade. Campinas, v.34, n. 123, abr.-jun. 2013. p. 551571.

WILLIS, Paul; TRONDMAN, Mats. Manifesto pela etnografia. Educação, Sociedades e Culturas, $\mathrm{n}^{\circ} .27,2008$. p. 211-220. 